\title{
Application of Linear Programming in Optimizing Labour Scheduling
}

\author{
Osama Yaseen M. Al-Rawi, Taniya Mukherjee \\ General Sciences Department, College of Engineering, Gulf University, Sanad, Kingdom of Bahrain \\ Email: dr.osama.alrawi@gulfuniversity.edu.bh, Taniya.mukherjee@gulfuniversity.edu.bh
}

How to cite this paper: Al-Rawi, O.Y.M. and Mukherjee, T. (2019) Application of Linear Programming in Optimizing Labour Scheduling. Journal of Mathematical Finance, 9, 272-285.

https://doi.org/10.4236/jmf.2019.93016

Received: May 18, 2019

Accepted: August 6, 2019

Published: August 9, 2019

Copyright $\odot 2019$ by author(s) and Scientific Research Publishing Inc. This work is licensed under the Creative Commons Attribution International License (CC BY 4.0).

http://creativecommons.org/licenses/by/4.0/

(c) (i) Open Access

\begin{abstract}
Employee or labor scheduling is associated with assigning an appropriate number of workers to the jobs during each day of work. It requires determining when staff members will work and when part-time, full-time workers will be needed to work. It is obvious that the number of employees wanted on duty throughout the week may fluctuate depending on health or family issues of the labor and the employer's requirement for a particular job; Scheduling forces us to systematically identify and analyze about all the tasks that need to be done on a project, the expected time each task might take, the expected requirement of the workforce for the job in terms of size and quality of employee personnel and the expected labor expenses. As the availabilities of the employees may vary and change from week to week; hence the scheduling becomes more essential for the smooth running of a project or shift. This paper focuses on a constructive method for solving Labor Scheduling problem encountered in a construction company, suggesting an estimated labor cost over a week and the requirement of part-time labors in each shift, using linear programming techniques, thus, providing a logical way to organize these tasks and produce a new schedule each week, by the virtue of the changing demand for service while minimizing labor cost and maximizing labor preferences.
\end{abstract}

\section{Keywords}

Optimization, Linear Programming, Staff Scheduling, Complex Scheduling Problem, Business

\section{Introduction}

Employee scheduling problems are commonly faced in the service industry [1] [2] which include the scheduling of nurses in hospitals [3] [4] [5] [6], scheduling 
of staffs in the hotel, check encoders in banks [7], airline [8] [9], and hotel reservation personnel, telephone operators, patrol officers, scheduling of waiter or waitresses in the restaurants, scheduling of laborers in the construction company and others. In a construction company, the scheduling process helps the contractor to formulate an overview of how the project is going to be laid. Detailed planning of schedule is prepared before execution starts in an area.

In their simplest form, the Scheduling which is a classic operation research problem provides the contractor with structured planning process while they are reviewing the plans and figuring out the sequence for building the project or the assignment of days-off, as in some of the less complex settings for the scheduling of nurses.

In a service organization or in a Construction company the front-line managers or contractors have to perform the important task of cost-effective labour scheduling. Serving the customers need, at a reasonable price requires a proper forecast of labour requirement. At any given time, having an inadequate number of employees or employees lacking the necessary job-skills-can result in substandard customer service; exasperated, overworked employees; and delay in completion of the project and lost sales. On the other hand, having excessive number of employees will increase: 1) the labour cost, 2) will reduce the operating margins, when extra hours are scheduled, or 3) from the employee's point of view will lower their morale and hamper job satisfaction if the working hours of the employees are fewer than they desire because the available work is spread thinly among many employees. Thus, labour or workforce scheduling is the process of balancing customer demand with employee work requests without compromising much on profitability.

\section{Literature Review}

There has been a lot of research on the various aspects of staff scheduling and rostering [1] [10]. Since this area has become increasingly important due to the business becoming more service oriented and cost-conscious in a global environment. Hence extensive Literature on Personnel scheduling [11] [12] [13], general workforce planning problems [14] and so on. are available. To trace the induction of staff scheduling and rostering we look into Edie's work on traffic delays at toll booths [15]. Since then, the application of scheduling of staff and rostering methods to transportation systems such as airlines [8] [9] [16] [17] [18] and railways [19] [20], health care systems [3] [4] [6], emergency services such as police [21], ambulance and fire brigade, call centers [22] [23] [24] [25], and many other service organizations such as hotels, restaurants and retail stores [26] [27] have increased manifold. This has led the foundation of focused studies and surveys on the scheduling objective models [12] [28] [29] [30] constraints [31] [32] and methodologies for each application area [10], leading to the future researches on the extensive model and algorithm development. Over the years, significant development of many computer software packages for staff scheduling, ranging from spreadsheet implementations of manual processes through to 
mathematical models using efficient optimal [5] [33] or heuristic algorithms [34] [35] [36] has taken place.

In some research, the study was concentrated in the adaptation and application of conventional mathematical programming on workforce planning problem such as linear programming [13], mixed linear programming [3] [26] [29] constraint programming [25] [30] [37] [38] mixed integer programming approach [17] [20] [27] [37] [39] [40] [41] [42] decomposition method [37] [43] branch and bound techniques[44], dynamic programming [45], goal programming [46] approaches in which the weighted coverage and shift satisfaction terms were given importance in the objective function. The constraints enforcing strict rules to be observed on shifts were discussed as well [30]. While some focus their study on iterative algorithms [10] [47]. The key problems related to staff/employee scheduling in different application area has been analyzed to obtain an optimal solution. From the research done in construction companies, it has been found that labor costs contribute for a large proportion of total project costs, i.e. in a way it can be concluded that labor cost is the major direct cost component in most of the companies. Though in construction areas or in industrial organizations most of the employee or workforce scheduling deals with full-time workers but now part-time employees [48] [49] are also extensively compensating the labor requirement. Research [32] [50], in this sector, shows that there are three types of problems namely, days off scheduling, shift scheduling [23] [51] [52], and tour schedule. Days off scheduling is related to the assignment of workers work and non-work days over the planning horizon. However, shift scheduling problem deals with determining the actual shifts (start and end times, breaks, etc.) in a planning horizon. And Tour scheduling problems combine features of both days off and shift scheduling. Here, it is to be noted that typically, work shifts are assigned to cover the daily demand for each shift, and each worker's days off schedule are taken care of. In the research literature of many key papers related to this area, integration of project task scheduling and staff scheduling has been studied and attempts were made to provide solutions. The objective in those papers was the determination of the number of staffs required on each day, based on proper scheduling of tasks, which would result in the minimization of the overall cost. Also in some papers research work was reported in the scheduling of engineers to carry out a variety of jobs located at different places where the main objectives were to maximize the amount of work done while minimizing the amount of time that gets wasted while transporting workers between locations [53]. Thus, enough researches regarding various aspects of labor or employee scheduling in various service sectors have initiated the research of my paper.

\section{Problem Formulation}

A labor scheduling problem is a complex process with multiple and contradictory objectives. In a labor scheduling problem generally, objectives are to $\mathrm{Mi}$ nimize the total labor cost, Minimizing the finishing time of the project while 
maximizing the laborer's preferences and requests without hampering the project schedule and ensuring equal distribution of workload between all the available laborers. In these cases, work constraints or the working hours of the laborers are according to the contracts and the laws of the Ministry of labor.

Constraints commonly occurring with Employee Scheduling Problems can be divided into; hard constraints and soft constraints.

Hard constraints are defined to be those which usually include coverage requirements (for example, labour demand per day per shift type per skill category) while soft constraints are usually, those which involved with time requirements on personal schedules. Our purpose is to schedule resources to meet the hard constraints while maintaining a high-quality result with respect to soft constraints.

However, the constraints [31] [32] commonly applicable to labor scheduling relates to:

1) Requirement of skilled labors in each shift.

2) Consecutive same working shift (minimum/maximum/exact number).

3) Shift type(s) assignments (maximum shift type, requirements for each shift types).

4) Maximum number of consecutive working days.

5) The minimum amount of leisure time between two shifts.

6) Days off (In the Middle East Friday is a day off).

7) A maximum number of hours worked.

8) No consecutive shifts are allowed for a particular labor.

\section{Application Area}

In a construction company when we are estimating for a particular the job we look for some vital information on the steps of production, an indication of what materials we need, when we need, the current cost of the materials, Whether the labor drivers are time variant or time-invariant, Determine the time interval for tracking the time variant labor drivers, an indication of how long the job will take, and any an unwanted situation which may affect the completion of the job. Tracking such records will give us an indication of how much labors we will need. In case, the work falls behind the permissible time, we may need more workers to complete the job within the assured schedule, as two employees have varying skills or desire to work the same number of hours and possibly avoid larger financial loss from penalization. The manager also needs to abide by government regulations, company policies, and contractual obligations. In a typical problem of this type, the scheduler needs to emphasize on appropriate days off to each of a number of employees who work standard shifts with different start times while assuring that the required number of employees are on duty throughout the day and week.

In the recent few years, the skyline of most of the Developed Countries has changed drastically. Many large-scale projects with the help of Local investors or 
international investors have been lined up to enhance the country's business and lifestyle. In a country like Bahrain, with Major construction projects like Expansion of Bahrain International Airport, investment in power and water projects, Gulf rail line development, the construction sector in Bahrain is expected to contribute a huge growth in real GDP. The proper finishing of projects is dependent on the scheduling process of laborers. And the goal in many researches was to produce support tools to lessen the need for manual construction of Labor distribution.

In a construction company, it is to be noted that the available labor is distributed into DIRECT LABOUR and INDIRECT LABOUR.

DIRECT LABOUR is related to the skilled labor operating machines and whose absence may affect the working in an operation site. However INDIRECT LABOUR is employees who are not directly related to the operation of machines.

\section{Structure of Linear Programming Model}

Generally, all LP problems [3] [17] [29] [31] [32] have these three properties in common:

1) OBJECTIVE FUNCTION: The objective function of an LPP (Linear Programming Problem) is a mathematical representation of the objective in terms of a measurable quantity such as profit, cost, revenue, etc.

Optimize (Maximize or Minimize) $Z=a_{1} x_{1}+a_{2} x_{1}+a_{3} x_{3}+\cdots+a_{n} x_{n}$. In most of the typical form, we look for maximizing the profit. However, in labor scheduling problem we look for minimizing Labor Cost.

2) CONSTRAINTS: The restrictions or constraints in an equation limit the degree to which we can pursue our objective.

$$
a_{1} x_{1}+a_{2} x_{1}+a_{3} x_{3}+\cdots+a_{n} x_{n} \leq b_{1}
$$

where $a_{1}, a_{2}, a_{3}, \cdots, a_{n}$ are parameters that contributes to decision variables.

3) DECISION VARIABLES: The various activities within the linear equation are represented by $x_{1}, x_{2}, x_{3}, \cdots, x_{n}$ is known as decision variables.

Therefore, LP means to maximize or minimize a quantity (the objective function) subject to limited resources (the constraints). It is desirable to express the objective and constraints in linear programming problems in terms of linear equations or inequalities.

\section{Assumptions in a Linear Programming Problem}

\section{Certainty}

All LP models are based on the assumption that all the model parameters such as availability of resources, profit (or cost) contribution of a unit of decision variable and consumption of resources by a unit of decision, the variable are known and constant.

Divisibility (Continuity)

Either whole numbers (integers) or mixed numbers (integer or fractional) are 
generally used to represent the solution values of the decision variables and resources. However, in some cases, Integer programming method may be employed depending on the desirability of only integer variables are solutions.

\section{Additivity}

The sum of the contributions (Profit or Cost) earned from each of the decision variables and the sum of the resources used by each decision variable should be equal to the value of the objective function for the assigned values of the decision variables and the accumulated sum of the available resources used, respectively. Thus, it is to be accepted that an objective function is the direct sum of the individual contributions of the different variables.

GENERAL MATHEMATICAL MODEL FOR LPP

Optimize (Maximize or Minimize) $Z=C_{1} X_{1}+C_{2} X_{2}+\cdots+C_{n} X_{n}$

Subject to constraints,

$$
\begin{gathered}
c_{11} x_{1}+c_{12} x_{2}+\cdots+c_{1 n} x_{n}(\leq \geq) b_{1} \\
c_{21} x_{1}+c_{22} x_{2}+\cdots+c_{2 n} x_{n}(\leq \geq) b_{2} \\
c_{31} x_{1}+c_{32} x_{2}+\cdots+c_{3 n} x_{n}(\leq \geq) b_{3} \\
\vdots \\
c_{m 1} x_{1}+c_{m 2} x_{2}+\cdots+c_{m n} x_{n}(\leq \geq) b_{m}
\end{gathered}
$$

and $x_{1}, x_{2}, \cdots, x_{n}>0$.

Steps followed for formulating Linear Programming model [3] [17] [20]

- Identifying and defining the decision variable of the given problem.

- Defining the objective function.

- Stating the constraints to which the objective function needs to be optimized (i.e. Maximization or Minimization).

- Adding the non-negative constraints.

Non-negative values have a physical interpretation; however negative values of the decision variables lack valid physical interpretation.

\section{Results}

Labor Scheduling aim is to allocate the sufficient number of staffs for each designated task while minimizing Labor cost. Reconstruction of the schedule with available staff is usually simple, however changing the schedule may lead to adjustments to other Job schedules as well. This is the daily report of the requirement of different categories of manpower for a particular job to be done on a particular shift in a day in a construction company $(1,0)$ represents the availability of that particular manpower for a particular shift. 1 for a particular cell represents that the particular category of employee is required for a scheduled job and 0 represents non-requirement of the particular category of employee [31]. The figs. in column 1 for $\mathrm{S} 1, \mathrm{~d} 1$ represents that the job assigned for day1, shift 1 requires FOREMAN, CARPENTER, MASON, LABOUR SITE ENGINEER and ELECTRICIAN. However, DRIVERS are not required for shift1. The data used for this study has been assumed. 
We now formulate this as a linear programming problem by setting up suitable constraints and objective function [3] [20] [21]. We first Identify and define the decision variable of the problem. Let $I$ be the index for different types of labor employed in a project. Where $1 \leq I \leq 7$. $X_{1}$ denotes No of Foreman, $X_{2}$ denotes No of Carpenter, $X_{3}$ denotes No of Masons, $X_{4}$ denotes No of Labors, $X_{5}$ denotes no of site engineers, $X_{6}$ denotes no of Electrician and $X_{7}$ denotes the number of Drivers.

Let $\mathrm{d}$ be the number of days in a scheduling period. Here we have considered 6 days in a period and we assume that the solution schedule is repeated. Where $1 \leq d \leq 6$. Let each day have 2 shifts denoted by $S=\{S 1, S 2\}$ where $S 1$ is the morning shift and $S 2$ is the evening shift [31].

$$
X_{I, d, S} \in[0,1]
$$

for each category of labour $I$, day $d$, shift $S$ those section of labor is either working the shift or not.

That means we can refer the scheduling by the 3-tuple $(I, d, S)$, as shown in Table 1.

$X(1,1, S 1)=1$ can be interpreted as that for the shift $S 1$ all the available FOREMAN are working the shift 1 on day 1 .

$X(3,2, S 2)=0$ means that no LABOURS are working on shift 2 of day 2 .

We Define the objective function

Min labor required in a day

$Z=\sum_{I=1}^{N} X_{I, d, S}$ when $d=\{1,2, \cdots, 6\}$ and shift $=\{S 1, S 2\}$

Min labor cost in a day

$$
Y=\sum_{d=1}^{6}\left(\sum_{I=1}^{N} C_{I} X_{I}\right)
$$

where $C_{I}$ is the daily wage of each type of labor depending on their rank in the office.

We now state the constraints which will determine the optimization of the objective function. In this case, the objective function is subjected to the following constraints, as shown in Table 2.

\begin{tabular}{|c|c|c|c|c|c|c|c|c|c|c|c|c|c|}
\hline $\begin{array}{l}\text { per day wage of } \\
\text { the labors (BD) }\end{array}$ & $\begin{array}{l}\text { different types } \\
\text { of labors }\left(X_{I}\right)\end{array}$ & $\mathrm{S}_{1, \mathrm{~d} 1}$ & $\mathrm{~S}_{2, \mathrm{~d} 1}$ & $\mathrm{~S}_{1, \mathrm{~d} 2}$ & $\mathrm{~S}_{2, \mathrm{~d} 2}$ & $\mathrm{~S}_{1, \mathrm{~d} 3}$ & $\mathrm{~S}_{2, \mathrm{~d} 3}$ & $S_{1, d 4}$ & $\mathrm{~S}_{2, \mathrm{~d} 4}$ & $\mathrm{~S}_{1, \mathrm{~d} 5}$ & $\mathrm{~S}_{2, \mathrm{~d} 5}$ & $\mathrm{~S}_{1, \mathrm{~d} 6}$ & $\mathrm{~S}_{2, \mathrm{~d} 6}$ \\
\hline 8 & FOREMAN & 1 & 0 & 1 & 1 & 1 & 1 & 1 & 1 & 0 & 1 & 1 & 1 \\
\hline 6 & CARPENTER & 1 & 1 & 0 & 0 & 1 & 1 & 0 & 1 & 1 & 1 & 1 & 1 \\
\hline 6 & MASON & 1 & 1 & 1 & 1 & 1 & 1 & 1 & 0 & 1 & 1 & 1 & 1 \\
\hline 7 & LABOUR & 1 & 1 & 1 & 1 & 1 & 1 & 1 & 1 & 1 & 1 & 1 & 1 \\
\hline 10 & SITE ENGG & 1 & 1 & 1 & 0 & 1 & 1 & 1 & 0 & 0 & 1 & 1 & 1 \\
\hline 5 & ELECTRICIAN & 1 & 0 & 0 & 0 & 1 & 1 & 1 & 1 & 1 & 1 & 0 & 1 \\
\hline 6 & DRIVERS & 0 & 1 & 0 & 1 & 0 & 1 & 0 & 1 & 1 & 1 & 0 & 0 \\
\hline \multicolumn{2}{|c|}{$\max$ labors } & 171 & 205 & 189 & 200 & 176 & 208 & 189 & 200 & 198 & 178 & 195 & 200 \\
\hline
\end{tabular}

Table 1. Labour availability per shift. 
Table 2. Labour availability per shift with minimum labour cost.

\begin{tabular}{|c|c|c|c|c|c|c|c|c|c|c|c|c|c|c|c|}
\hline \multirow{2}{*}{$\begin{array}{l}\text { Per day wage } \\
\text { of the labours }\end{array}$} & \multirow{2}{*}{$\begin{array}{l}\text { Different types } \\
\text { of labours (Xi) }\end{array}$} & \multicolumn{2}{|c|}{ day 1} & \multicolumn{2}{|c|}{ day 2} & \multicolumn{2}{|c|}{ day 3} & \multicolumn{2}{|c|}{ day 4} & \multicolumn{2}{|c|}{ day 5} & \multicolumn{2}{|c|}{ day 6} & \multirow{2}{*}{\multicolumn{2}{|c|}{ No of labours required }} \\
\hline & & S1 & S2 & S3 & S4 & S5 & S6 & S7 & S8 & S9 & S10 & S11 & S12 & & \\
\hline 8 & $X 1$-FOREMAN & 1 & 0 & 1 & 1 & 1 & 1 & 1 & 1 & 0 & 1 & 1 & 1 & $X 1=$ & 2 \\
\hline 6 & $X 2$-CARPENTER & 1 & 1 & 0 & 0 & 1 & 1 & 0 & 1 & 1 & 1 & 1 & 1 & $X 2=$ & 5 \\
\hline 6 & $X 3$-MASON & 1 & 1 & 1 & 1 & 1 & 1 & 1 & 0 & 1 & 1 & 1 & 1 & $X 3=$ & 10 \\
\hline 7 & $X 4$-LABOUR & 1 & 1 & 1 & 1 & 1 & 1 & 1 & 1 & 1 & 1 & 1 & 1 & $X 4=$ & 178 \\
\hline 10 & $X 5$-SITE ENGG & 1 & 1 & 1 & 0 & 1 & 1 & 1 & 0 & 0 & 1 & 1 & 1 & $X 5=$ & 1 \\
\hline 5 & X6-ELECTRICIAN & 1 & 0 & 0 & 0 & 1 & 1 & 1 & 1 & 1 & 1 & 0 & 1 & $X 6=$ & 4 \\
\hline 6 & $X 7$-DRIVERS & 0 & 1 & 0 & 1 & 0 & 1 & 0 & 1 & 1 & 1 & 0 & 0 & $X 7=$ & 11 \\
\hline
\end{tabular}

$\begin{array}{lllllllllllllll}\text { labours Available per shift } & 171 & 205 & 189 & 200 & 176 & 208 & 189 & 200 & 198 & 178 & 195 & 200 & \text { Min. Labours } & 211\end{array}$

$\begin{array}{llllllllllllll}\text { per shift labour requirement } & 200 & 205 & 191 & 201 & 200 & 211 & 195 & 200 & 208 & 211 & 196 & 200 & \text { Min. Labour COST } 1448\end{array}$

$$
\sum_{d=1}^{6} \sum_{I=1}^{N} X_{I, d, S} \geq K_{d S}
$$

where $K$ is the maximum labor available in each day $d$ in each shift $S$.

$$
\begin{aligned}
& X_{1,1, S 1}+X_{2,1, S 1}+X_{3,1, S 1}+X_{4,1, S 1}+X_{5,1, S 1}+X_{6,1, S 1}+0 \geq 171 \\
& 0+X_{2,1, S 2}+X_{3,1, S 2}+X_{4,1, S 2}+X_{5,1, S 2}+0+X_{7,1, S 2} \geq 205 \\
& X_{1,2, S 1}+0+X_{3,2, S 1}+X_{4,2, S 1}+X_{5,2, S 1}+0+0 \geq 189 \\
& X_{1,2, s 2}+0+X_{3,2, s 2}+X_{4,2, s 2}+0+0+X_{7,2, s 2} \geq 200 \\
& X_{1,3, S 1}+X_{2,3, S 1}+X_{3,3, S 1}+X_{4,3, S 1}+X_{5,3, S 1}+X_{6,3, S 1}+0 \geq 176 \\
& X_{1,3, s 2}+X_{2,3, s 2}+X_{3,3, s 2}+X_{4,3, s 2}+X_{5,3, S 2}+X_{6,3, S 2}+X_{7,3, S 2} \geq 208 \\
& X_{1,4, S 1}+0+X_{3,4, S 1}+X_{4,4, S 1}+X_{5,4, S 1}+X_{6,4, S 1}+0 \geq 189 \\
& X_{1,4, S 2}+X_{2,4, S 2}+0+X_{4,4, S 2}+0+X_{6,4, S 2}+X_{7,4, S 2} \geq 200 \\
& 0+X_{2,5, S 1}+X_{3,5, S 1}+X_{4, S, S 1}+X_{5,5, S 1}+X_{6,1, S 1}+0 \geq 198 \\
& X_{1,5, S 2}+X_{2,5, S 2}+X_{3,5, S 2}+X_{4,552}+X_{5,5, S 2}+X_{6,5 S 2}+X_{7,5, S 2} \geq 178 \\
& X_{1,6, S 1}+X_{2,6, S 1}+X_{3,6, S 1}+X_{4,6, S 1}+X_{5,6, S 1}+0+0 \geq 195 \\
& X_{1,6, S 2}+X_{2,6, S 2}+X_{3,6, S 2}+X_{4,6, S 2}+X_{5,6, S 2}+X_{6,6, S 2}+0 \geq 200 \\
& X_{I} \geq 0 \text { for all } I(I=1,2, \cdots, 7) \\
& X_{I}=\text { integer } \\
& X_{1} \geq 2, X_{2} \geq 5, X_{3} \geq 10, X_{4} \geq 40, X_{5} \geq 1, X_{6} \geq 4, X_{7} \geq 2
\end{aligned}
$$

Since the designed model has much Decision variables so the Excel Solver is used to solve LPP, the Optimal solution is to Minimize $Z=211$, asserting that 211 people are required when all the different kinds of manpower are used in the shift and $Y=1448$ is the minimum labour cost per day. It can be stated from the solution found by the linear programming algorithm (Excel-shown below) that the minimum number of 211 employees/staff are required to meet the daily requirement in a particular shift. And the minimum labour cost is 1448 units (BD). Also, from the constraints showing cell value less than the available employees for that shift and status, not binding can be explained that the particular 
shift is running short of a certain number of employees and the extra number of employees that need to be hired for the smooth running of the particular shift.

\section{Answer Report:}

Worksheet: [lpp solver.xlsx] Sheet 1

Report Created: 01-06-2018 10:40:38

Result: Solver found a solution. All Constraints and optimality conditions are satisfied, as shown in Figure 1.

Solver Engine

Engine: Simplex LP

Solution Time: 0.047 Seconds.

Iterations: 13 Subproblems: 0

Solver Options

Max Time Unlimited, Iterations Unlimited, Precision 0.000001

Max Subproblems Unlimited, Max Integer Sols Unlimited, Integer Tolerance $1 \%$, Assume Nonnegative

Objective Cell (Min)

$\begin{array}{llll}\text { Cell } & \text { Name } & \text { Original Value } & \text { Final Value } \\ \text { \$C\$13 } & \text { S1 } & 200 & 200\end{array}$

Variable Cells

$\begin{array}{lllll}\text { Cell } & \text { Name } & \text { Original Value } & \text { Final Value } & \text { Integer } \\ \text { \$P\$4 } & \text { FOREMAN } & 2.00 & 2.00 & \text { Integer } \\ \text { \$P\$5 } & \text { CARPENTER } & 5.00 & 5.00 & \text { Integer } \\ \text { \$P\$6 } & \text { MASON } & 10.00 & 10.00 & \text { Integer } \\ \text { \$P\$7 } & \text { LABOUR } & 178.00 & 178.00 & \text { Integer } \\ \text { \$P\$8 } & \text { SITE ENGG } & 1.00 & 1.00 & \text { Integer } \\ \text { \$P\$9 } & \text { ELECTRICIAN } & 4.00 & 4.00 & \text { Integer } \\ \$ P \$ 10 & \text { DRIVERS } & 11.00 & 11.00 & \text { Integer }\end{array}$

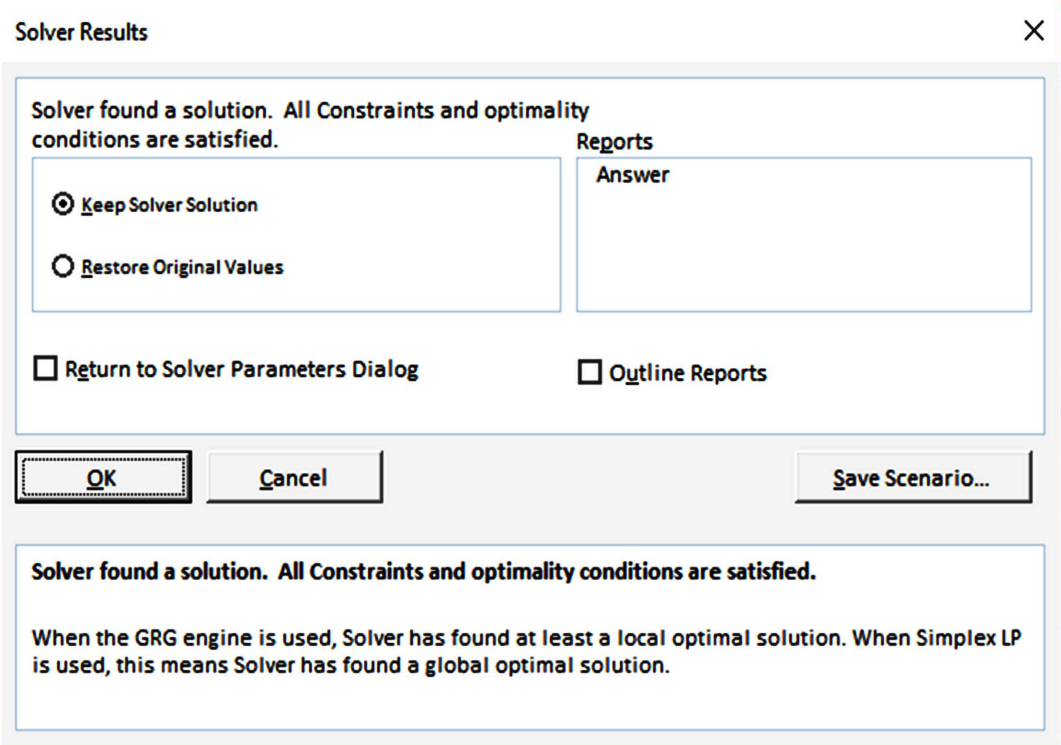

Figure 1. Solver results. 


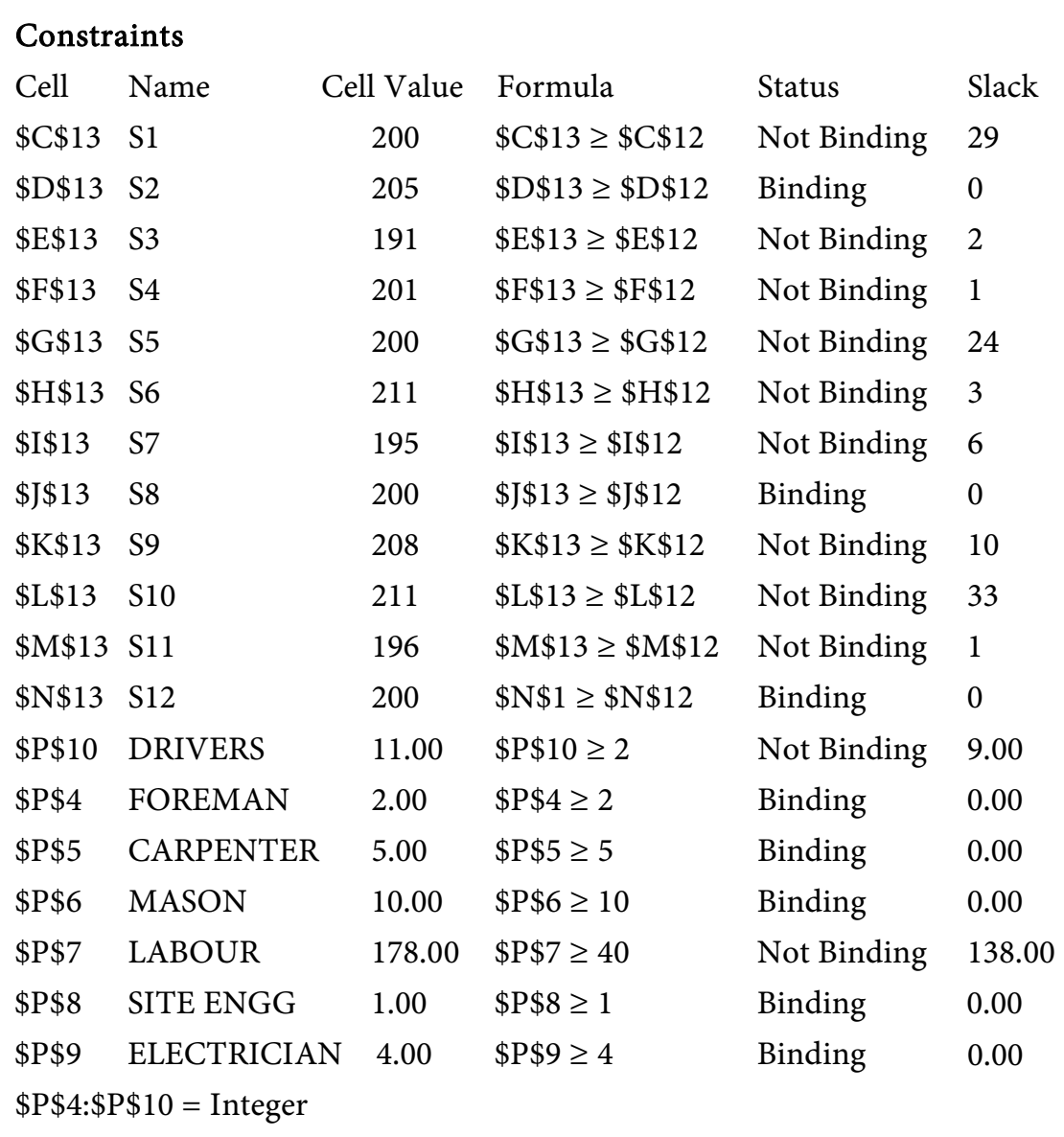

\section{Conclusion}

As discussed, Staff Scheduling is a complex scheduling problem that often affects the completion of a project in the construction farms all over. In this paper an overview of the planning and staff scheduling problem in a construction company is shown, which shows the minimum requirement of manpower for the proper execution of a job in each shift, the temporary employees that need to be hired from outside in order to meet the shift demands and the particular type of deficit employee that needs to be hired can also be stated, also the extra amount of money paid on temporary hire can be calculated. It is to be noted that the constraints described in this system are in terms of requirement of skilled labour and piece of works. The aim of this problem is to maximize the fairness of the schedule, while respectively all the constraints, thus, aiming at utilizing the time and effort efficiently, balancing the workload to lead more contented and effective outcomes.

\section{Acknowledgements}

The authors would like to thank the gulf university in Bahrain for their continuous support for scientific research and to attain the highest levels of the academic field. 


\section{Conflicts of Interest}

The authors declare no conflicts of interest regarding the publication of this paper.

\section{References}

[1] Pinedo, M., Zacharias, C. and Zhu, N. (2015) Scheduling in the Service Industries: An Overview. Journal of Systems Science and Systems Engineering, 24, 1-48. https://doi.org/10.1007/s11518-015-5266-0

[2] Semra Ağralı, Z., Taşkın, C. and Ünal, A.T. (2016) Employee Scheduling in Service Industries with Flexible Employee Availability and Demand. Omega, 66, 159-169. https://doi.org/10.1016/j.omega.2016.03.001

[3] Satheesh Kumar, B., Nagalakshmi, G. and Kumaraguru, S. (2014) A Shift Sequence for Nurse Scheduling Using Linear Programming Problem. IOSR Journal of Nursing and Health Science, 3, 24-28. https://doi.org/10.9790/1959-03612428

[4] De Grano, M.L., Medeiros, D.G. and Eitel, D. (2009) Accommodating Individual Preferences in Nurse Scheduling via Auctions and Optimization. Health Care Management Science, 12, 228-242. https://doi.org/10.1007/s10729-008-9087-2

[5] Moz, M. and Pato, M.V. (2007) A Genetic Algorithm Approach to a Nurse Rerostering Problem. Computers and Operations Research, 34, 667-691. https://doi.org/10.1016/j.cor.2005.03.019

[6] Maenhout, B. and Vanhoucke, M. (2013) An Integrated Nurse Staffing and Scheduling Analysis for Longer-Term Nursing Staff Allocation Problems. Omega, 41, 485-499. https://doi.org/10.1016/j.omega.2012.01.002

[7] Bagatourova, O. and Mallya, S.K. (2004) Coupled Heuristic and Simulation Scheduling in a Highly Variable Environment. Proceedings of the 2004 Winter Simulation Conference, Washington DC, 5-8 December 2004, 1856-1860. https://doi.org/10.1109/WSC.2004.1371540

[8] Brusco, M., Jacobs, L., Bongiorno, R., Lyons, D. and Tang, B. (1995) Improving Personnel Scheduling at Airline Stations. European Journal of Operational Research, 43, 728-905. https://doi.org/10.1287/opre.43.5.741

[9] Chu, S.C.K. (2007) Generating, Scheduling and Rostering of Shift Crew-Duties: Applications at the Hong Kong International Airport. European Journal of Operational Research, 177, 1764-1778. https://doi.org/10.1016/j.ejor.2005.10.008

[10] Ernst, A.T., Jiang, H., Krishnamoorthy, M. and Sier, D. (2004) Staff Scheduling and Rostering: A Review of Applications, Methods and Models. European Journal of Operational Research, 153, 3-27. https://doi.org/10.1016/S0377-2217(03)00095-X

[11] Van den Bergh, J., Beliën, J., De Bruecker, P., Demeulemeester, E. and De Boeck, L. (2013) Personnel Scheduling: A Literature Review. European Journal of Operational Research, 226, 367-385. https://doi.org/10.1016/j.ejor.2012.11.029

[12] Brucker, P., Qu, R. and Burke, E. (2011) Personnel Scheduling: Models and Complexity. European Journal of Operational Research, 210, 467-473. https://doi.org/10.1016/j.ejor.2010.11.017

[13] Pawar, U.S. and Hanchate, D.B. (2013) Literature Review on Personnel Scheduling. International Journal of Computer Engineering and Technology, 5.

[14] De Bruecker, P., Van den Bergh, J., Beliën, J. and Demeulemeester, E. (2015) Workforce Planning Incorporating Skills: State of the Art. European Journal of Operational Research, 243, 1-16. https://doi.org/10.1016/j.ejor.2014.10.038 
[15] Dantzig, G.B. (1954) Letter to the Editor: A Comment on Edie's 'Traffic Delays at Toll Booths'. Operations Research, 2, 229-361. https://doi.org/10.1287/opre.2.3.339

[16] Casado, S., Laguna, M. and Pacheco, J. (2005) Heuristical Labour Scheduling to Optimize Airport Passenger Flows. Journal of the Operational Research Society, 56, 649-658. https://doi.org/10.1057/palgrave.jors.2601859

[17] De Bruecker, P., Van den Bergh, J., Belien, J. and Demeulemeester, E. (2015) A Two-Stage Mixed Integer Programming Approach for Optimizing the Skill Mix and Training Schedules for Aircraft Maintenance. Social Science Research Network. https://doi.org/10.2139/ssrn.2697491

[18] Thiel, M.P. (2008) Team-Oriented Airline Crew Rostering for Cockpit Personnel. In: Hickman, M., Mirchandani, P. and Voß, S., Eds., Computer-Aided Systems in Public Transport. Lecture Notes in Economics and Mathematical Systems, Springer, Berlin, Heidelberg, 600, 91-114. https://doi.org/10.1007/978-3-540-73312-6_6

[19] Hoong, C.L., Zhi, Y. and Aldy, G. (2016) Patrol Scheduling in Urban Rail Network. Annals of Operations Research, 239, 317-342.

https://doi.org/10.1007/s10479-014-1648-9

[20] Pour, S.M., Drake, J.H., Ejlertsen, L.S., Rasmussen, K.M. and Burke, E.K. (2018) A Hybrid Constraint Programming/Mixed Integer Programming Framework for the Preventive Signaling Maintenance Crew Scheduling Problem. European Journal of Operational Research, 269, 341-352. https://doi.org/10.1016/j.ejor.2017.08.033

[21] Kolesar, P.J., Rider, K.L., Crabill, T.B. and Walker, W.E. (1975) A Queuing-Linear Programming Approach to Scheduling Police Patrol Cars. Operations Research, 23, 1045-1062.

[22] Chanpanit, T. and Udomsakdigool, A. (2015) Workforce Planning for Single Call Center with Service Level Agreement. In: Kachitvichyanukul, V., Sethanan, K. and Golinska-Dawson, P., Eds., Toward Sustainable Operations of Supply Chain and Logistics Systems. EcoProduction (Environmental Issues in Logistics and Manufacturing), Springer, Cham, 521-533. https://doi.org/10.1007/978-3-319-19006-8_36

[23] Bhulai, S., Koole, G. and Pot, A. (2008) Simple Methods for Shift Scheduling in Multiskill Call Centers. Manufacturing \& Service Operations Management, 10, 337-562. https://doi.org/10.1287/msom.1070.0172

[24] Dietz, D.C. (2011) Practical Scheduling for Call Center Operations. Omega, 39, 550-557. https://doi.org/10.1016/j.omega.2010.12.001

[25] Canon, C. (2007) Personnel Scheduling in the Call Center Industry. 4OR, 5, 89-92. https://doi.org/10.1007/s10288-006-0008-2

[26] Parisio, A. and Jones, C.N. (2015) A Two-Stage Stochastic Programming Approach to Employee Scheduling in Retail Outlets with Uncertain Demand. Omega, 53, 97-103. https://doi.org/10.1016/j.omega.2015.01.003

[27] Henao, C.A., Muñoz, J.C. and Ferrer, J.C. (2015) The Impact of Multi-Skilling on Personnel Scheduling in the Service Sector: A Retail Industry Case. Journal of the Operational Research Society, 66, 1949-1959. https://doi.org/10.1057/jors.2015.9

[28] Thomas, P.I. (2013) Scheduling Algorithm with Optimization of Employee Satisfaction.

[29] Jaumard, B., Semet, F. and Vovor, T. (1998) A Generalized Linear Programming Model for Nurse Scheduling. European Journal of Operational Research, 107, 1-18. https://doi.org/10.1016/S0377-2217(97)00330-5

[30] Thompson, G.M. (1995) Improved Implicit Optimal Modeling of the Labor Shift Scheduling Problem. Management Science, 41, 595-607. 
[31] Cheang, B., Li, H., Lim, A. and Rodrigues, B. (2003) Nurse Rostering Problems: A Bibliographic Survey. European Journal of Operational Research, 151, 447-460. https://doi.org/10.1016/S0377-2217(03)00021-3

[32] Van den Bergh, J., Beliën, J., De Bruecker, P., Demeulemeester, E. and De Boeck, L. (2013) Personnel Scheduling: A Literature Review. European Journal of Operational Research, 226, 367-385. https://doi.org/10.1016/j.ejor.2012.11.029

[33] Cai, X. and Li, K. (2000) A Genetic Algorithm for Scheduling Staff of Mixed Skills under Multi-Criteria. European Journal of Operational Research, 125, 359-369. https://doi.org/10.1016/S0377-2217(99)00391-4

[34] Hewitt, M., Chacosky, A., Grasman, S. and Thomas, B. (2015) Integer Programming Techniques for Solving Non-Linear Workforce Planning Models with Learning. European Journal of Operational Research, 42, 942-950.

https://doi.org/10.1016/j.ejor.2014.10.060

[35] Li, G., Jiang, H. and He, T. (2015) A Genetic Algorithm-Based Decomposition Approach to Solve an Integrated Equipment-Workforce-Service Planning Problem. Omega, 50, 1-17. https://doi.org/10.1016/j.omega.2014.07.003

[36] Aickelin, U. and Dowsland, K.A. (2004) An Indirect Genetic Algorithm for a Nurse-Scheduling Problem. Computers \& Operations Research, 31, 761-778. https://doi.org/10.1016/S0305-0548(03)00034-0

[37] Harjunkoski, I. and Grossmann, I.E. (2002) Decomposition Techniques for Multistage Scheduling Problems Using Mixed-Integer and Constraint Programming Methods. Computers \& Chemical Engineering, 26, 1533-1552.

https://doi.org/10.1016/S0098-1354(02)00100-X

[38] Baptiste, P., Le Pape, C. and Nuijten, W. (2003) Constraint-Based Scheduling: Applying Constraint Programming to Scheduling Problems. Journal of Scheduling, 6, 413-414.

[39] Hertz, A., Lahrichi, N. and Widmer, M. (2010) A Flexible MILP Model for Multiple-Shift Workforce Planning under Annualized Hours. European Journal of Operational Research, 200, 860-873. https://doi.org/10.1016/j.ejor.2009.01.045

[40] Cuevas, R., Ferrer, J.-C., Klapp, M. and Muñoz, J.-C. (2016) A Mixed Integer Programming Approach to Multi-Skilled Workforce Scheduling. Journal of Scheduling, 19, 91-106. https://doi.org/10.1007/s10951-015-0450-0

[41] Azmat, C.S., Hurlimann, T. and Widmer, M. (2004) Mixed Integer Programming to Schedule a Single-Shift Workforce under Annualized Hours. Annals of Operations Research, 128, 199-215. https://doi.org/10.1023/B:ANOR.0000019105.54898.a4

[42] Al-Yakoob, S.M. and Sherali, H.D. (2007) Multiple Shift Scheduling of Hierarchical Workforce with Multiple Work Centers. Informatica, 18, 325-342.

[43] Harjunkoski, I. and Grossmann, I.E. (2001) A Decomposition Approach for the Scheduling of Steel Plant Production. Computers \& Chemical Engineering, 25, 1647-1660. https://doi.org/10.1016/S0098-1354(01)00729-3

[44] Abril, F.C. and Alvarez, C.M. (2005) Scheduling Resource-Constrained Projects Using Branch and Bound and Parallel Computing Techniques. International Journal of Operational Research, 1.

[45] Mirmohseni, S.M., Nasseri, S.H. and Khaviari, M.H. (2017) A New Fuzzy Hybrid Dynamic Programming for Scheduling Weighted Jobs on Single Machine. Journal of Applied Research on Industrial Engineering, 4, 97-115.

[46] Azaiez, M.N. and Al Sharif, S.S. (2005) A 0-1 Goal Programming Model for Nurse Scheduling. Computers \& Operations Research, 32, 491-507. 
https://doi.org/10.1016/S0305-0548(03)00249-1

[47] Novoa, D., Olarte, C., Barrera, D. and González-Neira, E.M. (2016) A GRASP-Based Approach to the Multi Activity Combined Timetabling and Crew Scheduling Problem Considering a Heterogeneous Workforce. International Journal of Industrial Engineering Computations, 7, 597-606. https://doi.org/10.5267/j.ijiec.2016.4.001

[48] Akbari, M., Zandieh, M. and Dorri, B. (2012) Scheduling Part-Time and Mixed-Skilled Workers to Maximize Employee Satisfaction. The International Journal of Advanced Manufacturing Technology, 64, 1017-1027. https://doi.org/10.1007/s00170-012-4032-4

[49] Hojati, M. and Patil, A.S. (2011) An Integer Linear Programming-Based Heuristic for Scheduling Heterogeneous, Part-Time Service Employees. European Journal of Operational Research, 209, 37-50. https://doi.org/10.1016/j.ejor.2010.09.004

[50] Baker, K.R. (1976) Workforce Allocation in Cyclical Scheduling Problems: A Survey. Journal of the Operational Research Society, 27, 155-167. https://doi.org/10.1057/jors.1976.30

[51] Azmat, C.S. and Widmer, M. (2004) A Case Study of Single Shift Planning and Scheduling under Annualized Hours: A Simple Three-Step Approach. European Journal of Operational Research, 153, 148-175. https://doi.org/10.1016/S0377-2217(03)00105-X

[52] Di Gaspero, L., Gärtner, J., Kortsarz, G., Musliu, N., Schaerf, A. and Slany, W. (2007) The Minimum Shift Design Problem. Annals of Operations Research, 155, 79-105. https://doi.org/10.1007/s10479-007-0221-1

[53] Sadat, Z., Nadoushani, M., Hammad, A.W.A. and Akbarnezhad, A. (2017) Location Optimization of Tower Crane and Allocation of Material Supply Points in a Construction Site Considering Operating and Rental Costs. Journal of Construction Engineering and Management, 143, Article ID: 04016089. https://doi.org/10.1061/(ASCE)CO.1943-7862.0001215 